\title{
A Study of Success Factors in Green Supply Chain Management in Manufacturing Industries in Malaysia
}

\author{
Norlinda Mohd Rozar, Wan Hasrulnizzam Wan Mahmood, Abdullah Ibrahim, and Muhammad \\ Ashlyzan Razik
}

\begin{abstract}
Environmental issues have become a notably prevalent concern for governments, societies and business organizations. With environmental problems such as global warming, ozone depletion, solid waste and air pollution, business organizations are considered to be the source of most of the environmental problems. In Malaysia, manufacturing industry is one of the main contributors for the economic growth. Unfortunately, it has been caused for environmental deterioration. (DOE, 2013). In order to investigate further understand GSCM among manufacturers in Malaysia, This study has carry out survey to 241 of 522 certified companies MS ISO 14001 in Malaysia is $\mathbf{5 2 2}$ companies. One of the results are consistent with the study of Rao (2007) who found that there is a manufacturing company that cannot sell and distribute raw materials internally to other companies or external use as raw material and subject to confidentiality policies. It is the raw material control gives a competitive edge in the market, especially in industries that are based on advanced technology (Zhu et al. 2012).
\end{abstract}

Index Terms-Green supply chain management, manufacturers.

\section{INTRODUCTION}

Environmental issues have become a notably prevalent concern for governments, societies and business organizations. With environmental problems such as global warming, ozone depletion, solid waste and air pollution, business organizations are considered to be the source of most of the environmental problems. In Malaysia, manufacturing industry is one of the main contributors for the economic growth. Unfortunately, it has been caused for environmental deterioration [1]. This is because the industries produce more emissions compare to other industries when manufacturing the productivity in order to fulfill consumer needs and demands. For example, since 2007 to 2009, the number of water pollution contributed by

Manufacturing industry have been gradually increased as indicated in Table I.

Thus figure indicated that manufacturing industry is one of the main contributors to the deterioration of environmental sustainability. Thus, the concept of green supply chain management (GSCM is now gaining importance since it can help to minimize negative impact of the industrial processes but can also enhance the competitive advantage of the firms [2].

This study looks at the green initiatives and factors that triggered such initiatives among manufacturers in Malaysia.

Manuscript received September 11, 2013; revised November 12, 2013.

Norlinda Mohd Rozar is with the North University Malaysia, Malaysia (e-mail: nuhasya@hotmail.com).
Malaysian manufacturing sector has remained to be an important contributor to Malaysian economy. In the three quarter of 2009, value-added of the manufacturing sector declined by 13.7 percent given the less favorable external economic environment. The sector accounted for 26.8 percent of gross domestic product (GDP) during this period. Transition exports of manufactured products decreased by 14.1 per cent from RM432.6 billion in 2008 (January-November) to RM371.5 billion in 2009 (January-November), accounting for 74.5 per cent of Malaysia's total exports from January to November 2009. Employment in manufacturing sector was estimated at 3.3 million peoples or 28.4 per cent of total employment in 2009 [3].

TABLE I: NumBer of WATER POLLUTION POINT SOURCES PRODUCED BY MANUFACTURING INDUSTRY (2005-2010)

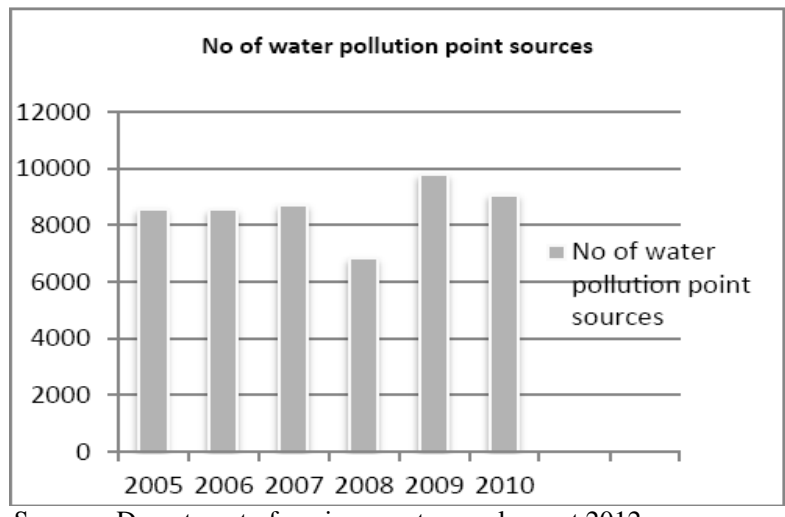

Sources: Department of environment annual report 2012

Essentially, in green initiative has taken seriously by the Malaysian government [1]-[4]. Such as Environmental Quality Act of 1974 and other environmental laws are administered by the Division of Environment. Clean-air legislation was adopted in 1978, limiting industrial and automobile emissions and included the use of environment-friendly biomass boilers, its various corporate social responsibility initiatives. Example, in Taman Suria, Batang Berjuntai, it spending over RM5mil annually to treat effluents and emissions to ensure that these met requirements, [1]. Malaysia had attracted almost RM12 billion in investments from the solar photovoltaics industry through FDIs, from top companies such as First Solar, Sun Power, Q-Cells and Tokuyama, [4].

The situation that's raise to the arguments question is "How extent the GSCM implementation in manufacturing industries and what are the success factors to ensure the implementation of GSCM will influence to the impact of firms performance? 


\section{LITERATURE REVIEW}

\section{A. Green Supply Chain Management}

In order to realize the sustainable development of eco-friendly, controlled use of natural resources enhanced to minimize the negative influence on the environment. To focus on green technology applications in every industrial activity including supply is believed to affect the performance of the global environment. It includes the development and application of products, equipment, systems and natural resources that can reduce the negative effects of human activities [5].

Literature proves that the organization should adopt green technology approach for being an environmentally friendly company social responsibility. Manaktola and Jauhari (2007) [6]. found that environmental sustainability efforts need to involve multiple parties, including customers and suppliers in a supply chain. It is supported by Baharum and Pitt (2009) [7] that identifies the key success factors in green practices also influenced by external third parties or companies. Various approaches have been used to improve the efficiency of green technology. However, this study focuses on the green supply chain management (or GSCM), which is an important approach in generating breakthrough green technology applications ([8]. Rao (2007) [9]. Found that GSCM is innovative in the supply chain management and operational performance driven environment, including environmental management systems (EMS) and ISO 14001 certification. The increase in environmental regulations Pilkington \& Dyerson (2006) [10]. Urged the organization to join the GSCM and increase competition in terms of product manufacturing, inventory management, suppliers, customers, and systems infrastructure in a global supply chain management [11].

There are various definitions and concepts have been discussed in the literature, however, there is no special definition describes GSCM and its applications [12]-[15]. GSCM can be defined according to the study of philosophy in which the elements of supply chain management (or SCM) and the environment are combined in one concept [16]-[5]. It depends on the perspective and purpose of GSCM implementation in an organization [17]. Kovács (2008) [18]. Defines the GSCM as a strategy to minimize the negative impact on the environment through activities within the organization and supply chain. It also prioritizes cooperation with suppliers and customers in the product development process [19]. Vachon and Klassen (2006A) [12]. Found that the cooperation between suppliers and customers to improve organizational performance. In fact, Hart (1995) [20]. Found that the implementation of GSCM improve information sharing capabilities that provide a competitive advantage to the organization in line with the process of environmental sustainability.

\section{B. Critical Success Factors for the Implementation GSCM}

Beamon (1999) [21]. found that the identification requirement or customer focus is the key critical success factor in GSCM including companies in China [22]. As well as several companies in Southeast Asia [17]-[23]. Laroche et al . (2001) [24] argues that this factor influenced the trend that customers are now more aware of the environment. Global negative effects on the environment gives a reminder to all members of the community that this problem is a shared responsibility [25]. Therefore, meet customer requirements including product attributes that influence the value and cost can give a positive result of investments in the GSCM [26].

Organizations need to act proactively in order to improve the operational efficiency of production as competition has become more competitive [27]. It is driven by the actions of some customers to reduce the cost of purchase for the next year without affecting the output capacity [28]. Zhu and Sarkis (2004) [16], pointed out that organizations need to be sensitive to changes during operation and maximize production with the application of green technology as an agent in continuous improvement activities.

\section{METHODS}

In order to investigate further understand GSCM among manufacturers in Malaysia, The number of certified companies MS ISO 14001 in Malaysia until 2009 is 522 companies. However, only about 241 selected as the study population. The judgmental sampling was used in the selection process. This method was chosen because the researchers targets specific type or subjects who have the expertise or information that very important to the study. The objectives of the study are to investigate GSCM among manufacturers in Malaysia. Therefore firms with ISO 14001 certification have been chosen to take part in the interviews. The reason why this type of companies were selected because the ISO 14001 certified companies were selected because they were expected to adopt the green initiatives within their operations [29]. Since this research solicits information on green issues operations, the best person that should be the respondent from each firm is the person who possesses knowledge and information on this field. Standards and Industrial Research Institute of Malaysia (SIRIM) as the certification organization for ISO 14001 usually appoint an Environmental Management Representatives (EMR) to act as a link between the certification organization and the certified firms [29]. The interview sessions were held at respondents' premises and each session took about one hour. The interviews were semi structured but guided by a list of open ended questions. Prior to the interview sessions, the interviewer gave a brief explanation on the study.

Immediately after the interviews, the information was transcribed for further analysis. These interviews were conducted as the supplement for a survey questionnaire of 116 firms, which served as another component in the data collection process. However, only the findings from the case study are discussed for this paper. Based on Yin (2003) [30]. Data analysis in this study started with an in depth study of each firm. The cases were then compared with other cases in cross case analysis to see the pattern of GSCM factors and practices.

\section{RESEARCH FINDING}

Fig. 1 shows the mean scores GSCM critical success factor for the company in the form of graphs respondents prioritized the highest mean score to lowest mean score. The mean score for all factors above 3.00 indicating a positive response by the respondent to the list of critical success factors listed in the 
survey. Results clearly show that each critical success factor has a role in the GSCM as study Rao (2002, 2007)[17]-[9].Found that identifying customer needs and focus , CSF1 is a critical success factor GSCM most important among the respondents with the mean score of 3.63. The results support the study of Zhu and Sarkis (2004) [16]. Who found that customers are now more aware of environmental problems and successes GSCM highly influenced by the customer. In the meantime, ensure customer complaints are handled properly, CSF 6, is the second major factor for the success of GSCM. It will be noted that these factors are also associated with the customer factor, but it is more proactive [31]. This is because; the complaint also is a claim that should be met to obtain customer satisfaction in the long run [32]. However, it is also subject to the organization's dependence on customers because for some products, the customer was not directly involved in product improvement activities [33].
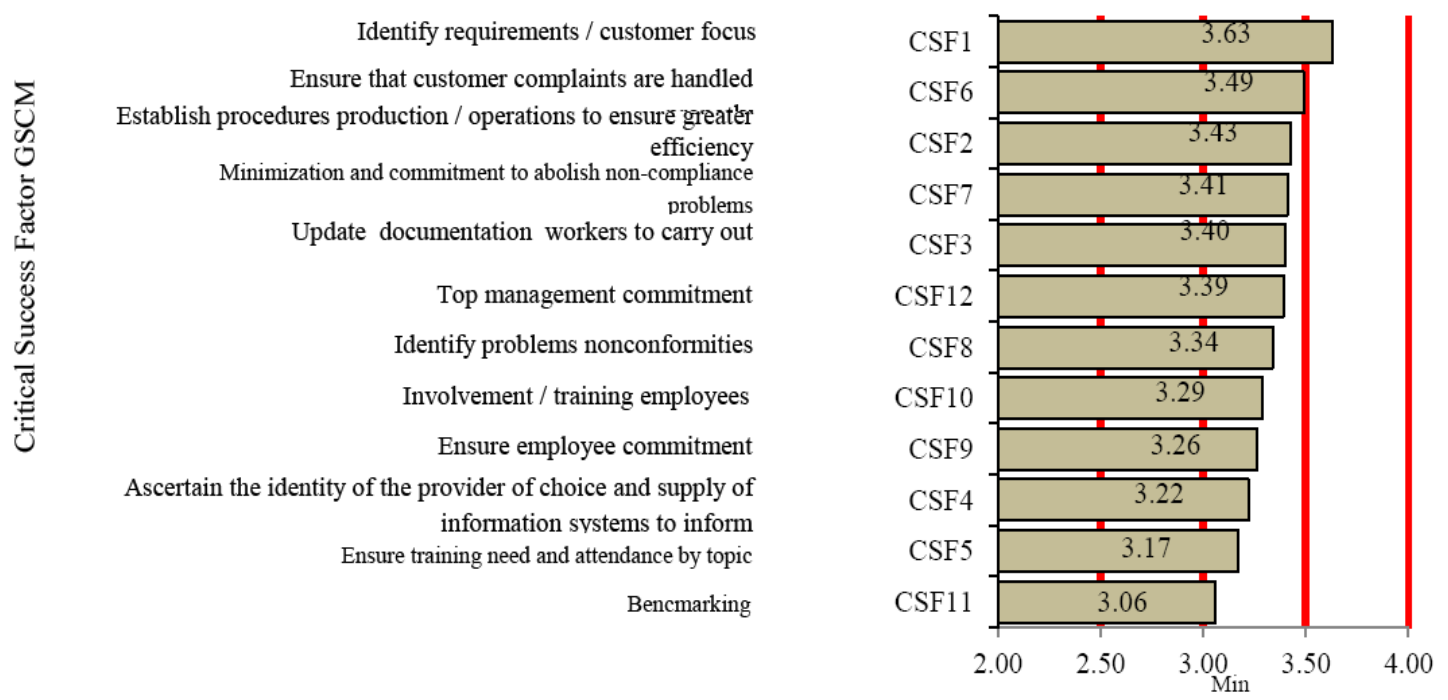

Fig. 1. Mean score of critical success factors GSCM.

Table II shows the Spearman correlation test results for the critical success factors GSCM. Found that most of the factors have significant relationships with other critical success factors in the level of 0.01 and 0.05 , except the couple of factors determine the production or operating procedures to ensure increased efficiency, CSF2, and ensure training needs, attendance by topic, CSF5, and identify requirements and customer focus, CSF1 to update the documentation to ensure that workers perform tasks, CSF3 and ensure customer complaints are handled properly, CSF6. From Table II found employee involvement and training, and to identify problems CSF10 nonconformities, CSF10 have a strong correlation. It was followed by a couple of factors that ensure employees update documentation for the job, and ensure minimization CSF3 and commitment to nonconformities problem repeal, CSF7 a moderately strong correlation strength. These results indicate that each of these factors is interrelated to one another influential. In other words, the activities in the critical success factors GSCM also have an impact on other factors though the correlation weak or very weak.

TABLE II: SPEARMAN CORRELATION TEST RESULTS FOR THE CRITICAL SUCCESS FACTORS GSCM

\begin{tabular}{|c|c|c|c|c|c|c|c|c|c|c|c|}
\hline $\begin{array}{l}\text { Critical } \\
\text { Success } \\
\text { Factor } \\
\text { of GSCM }\end{array}$ & CSF1 & CSF2 & CSF3 & CSF4 & CSF5 & CSF6 & CSF7 & CSF8 & CSF9 & CSF10 & CSF11 \\
\hline CSF2 & $0.593 * *$ & & & & & & & & & & \\
\hline CSF3 & 0.152 & $0.400^{* *}$ & & & & & & & & & \\
\hline CSF4 & $0.398^{* *}$ & $0.507^{* *}$ & $0.614^{* *}$ & & & & & & & & \\
\hline CSF5 & $0.250^{*}$ & 0.178 & $0.400^{* * *}$ & $0.457 * *$ & & & & & & & \\
\hline CSF6 & 0.084 & $0.206^{*}$ & $0.604^{* *}$ & $0.375^{* *}$ & $0.366^{* * *}$ & & & & & & \\
\hline CSF7 & $0.195^{*}$ & $0.443 * *$ & $0.679 * *$ & $0.468^{* * *}$ & $0.426^{* * *}$ & $0.583^{* * *}$ & & & & & \\
\hline CSF8 & $0.376^{* *}$ & $0.514^{* *}$ & $0.339^{* *}$ & $0.366^{* *}$ & $0.536^{* *}$ & $0.326^{* *}$ & $0.493^{* *}$ & & & & \\
\hline CSF9 & $0.355^{* *}$ & $0.495 * *$ & $0.478^{* * *}$ & $0.503^{* * *}$ & $0.432^{* *}$ & $0.414 * *$ & $0.518^{* *}$ & $0.572^{* * *}$ & & & \\
\hline CSF10 & $0.412 * *$ & $0.482 * *$ & $0.248^{*}$ & $0.387^{* *}$ & $0.545^{* *}$ & $0.217^{*}$ & $0.403^{* *}$ & $0.714^{* * *}$ & $0.618^{* *}$ & & \\
\hline CSF11 & $0.333^{* *}$ & $0.392 * *$ & $0.313^{* *}$ & $0.451^{* *}$ & $0.479^{* *}$ & $0.355^{* *}$ & $0.383^{* *}$ & $0.409^{* *}$ & $0.457^{* *}$ & $0.546^{* *}$ & \\
\hline CSF12 & $0.300^{* *}$ & $0.493 * *$ & $0.365^{* *}$ & $0.493^{* * *}$ & $0.436^{* *}$ & $0.274 * *$ & $0.278 * *$ & $0.574 * *$ & $0.333^{* *}$ & $0.556^{* *}$ & $0.451^{* *}$ \\
\hline
\end{tabular}

These results support the study Vachon and Klassen (2006A, 2006b) [12]. Have also found that there is a critical success factor significantly interrelated. Sarkis (2006) [5]. Found critical success factors is the "soft factors" are not easy to implement, but it has in common with each other that can be complementary in GSCM. In fact, it also can create a work environment more manageable [35]. Therefore, identifying the relationship between critical success factors will motivate organizations to choose or pay more attention to the factors that are relevant to the workplace environment, particularly in supply chain management.

Malaysian manufacturing companies prefer to use 
recycled materials as compared with material internal or external recycling companies. Chiang et al. (2010) [36]. Found that manufacturing companies to do so in order to optimize existing resources but it can provide the raw material cost savings and continuous improvement to product processing methods. These results are also consistent with the study of Rao (2007) [9]. Who found that there is a manufacturing company that cannot sell and distribute raw materials internally to other companies or external use as raw material and subject to confidentiality policies? It is the raw material control gives a competitive edge in the market, especially in industries that are based on advanced technology [14].

\section{Implication}

Investigate why and what companies are doing at the moment in terms of GSCM practices enable practitioners and researchers to think about strategies that can bring better results. Future studies should focus on the relationship between GSCM factors and practices of Malaysian manufacturers. Identification and analysis of the current situation is the main contribution of this paper to the body of knowledge. Managers need to be aware of the pressures that drive companies to engage with GSCM practices. Good managers will respond and act accordingly to the pressure received by their firm but the best managers will think and be proactive in analyzing factors that urged them to take green initiatives. In addition, managers must be aware of the capacity and ability of their firms before implementing any green practices. Making good decisions in determining green activities to be implemented in firms will lead to better results without compromising their business objectives to maximize shareholder wealth.

\section{CONCLUSION}

Results of this study show that GSCM is now gaining momentum in Malaysia. The firm began implementing green practices and it probably will continue because there is a demand and some push and pull factors that encourage them to do so. From the interview, it is known that those four firms merge GSCM to meet the needs of their customers, in order to comply with applicable laws and regulations, as a marketing strategy, to become more competitive in the market and as influenced by the commitment and support of the their top management . Acceptance GSCM practices vary depending on the firm's products and services. Basically, companies involved in green purchasing and implementing green practices internal as their efforts to support the greening of the supply chain. In addition, some companies do logistics, reverse eco design and work with their chain partners in maintaining green business strategy. Although still relatively new GSCM approach in Malaysia, it has been implemented by manufacturing firms in Malaysia.

\section{REFERENCES}

[1] Department of Environment (DOE), Department of Environment Annual Report, Number of water pollution sources by manufacturing industry, 2010 .

[2] P. Rao, "Greening of suppliers/in-bound logistics in the South East Asian context," in J. Sarkis (Ed), Greening the Supply Chain, London: Springer, 2006.
[3] Ministry of Finance. (2010). Economic Report 2009/2010. [Online]. Available: http://www.mof.gov.my.

[4] K. Tenaga and T. H. dan Air. (2010). National Green Technology Policy. [Online]. Available: http://www.greentechmalaysia.my/

[5] J. Sarkis, Greening the Supply Chain, Ch. 11, Springer, London, pp. 189-204, 2006.

[6] K. Manaktola and V. Jauhari, "Exploring consumer attitude and behavior towards green practices in the lodging industry in India," International Journal of Contemporary Hospitality Management, vol. 19, no. 5, pp. 364-377, 2007.

[7] M. R. Baharum and M. Pitt, "Determining a conceptual framework for green FM intellectual capital," Journal of facilities Management, vol. 7, no. 4, pp. 267-282, 2009.

[8] J. H. Cheng, C. H. Yeh, and C. W. Tu, "Trust amd knowledge sharing in green supply chains- moderating by relational benefits and Guanxi," Transportation Research Part E: Logistics and Transporatation Review, vol. 47, no. 6, pp. 837-849, 2008.

[9] P. Rao, "Greening of supply chain: An empirical study for SMEs in Philipine Context," Journal of Asia Busness Studies, vol. 55, no. 66, 2007.

[10] A. Pilkington and R. Dyerson, "Innovation in disruptive regulatory environments: A patent study of electric vehicle technology development," European Journal of Innovation Management, vol. 9 , no. 1, pp. 79-91, 2006.

[11] I. Manuj and J. T. Mentzer, "Global supply chain risk, management strategies," International Journal of Physical Distribution and Logistics Management, vol. 38, no. 3, pp. 192-223.

[12] S. Vachon and R. D. Klassen, "Green porject partnership in the supply chain: the case of the package printing industring," Journal of Cleaner Production, vol. 14, pp. 661-671, 2006.

[13] S. K. Srivastava, "Green supply chain management: A state-of-the-art literature review," International Journal of Management Reviews, vol. 9, no. 1 , pp. 53-80, 2008

[14] Q. Zhu, J. Sarkis, and K.-H. Lai, "Green supply chain management innovation diffusion and its relationship to organizational improvement: An ecological modernization perspective," Journal of Engineering and Technology Management, vol. 29, no. 1, 2012.

[15] S. A. Seuring, "Outsourcing into service factories: An exploratory analysis of facility operators in the German chemical industry," International Journal of Operations \& Production Management, vol. 23, no. 10, pp. 1207-1223, 2003.

[16] Q. Zhu and J. Sarkis, "Relationships between operational practices and performance among early adopters of green supply chain management practices in Chinese manufacturing enterprises," Journal of Operation Management, vol. 22, pp. 265-289, 2004.

[17] P. Rao, "Greening the supply chain: A new initiative in South East Asia," International Journal of Operations \& Production Management, vol. 22 , no. 6, pp. 632-655, 2002.

[18] G. Kovacs, "Corporate environmental responsibilities in the supply chain," Journal of Cleaner Production, vol. 16, no. 5, pp. 1571-1578, 2008.

[19] C. Corbett and L. V. Wassenhove, "Environmental issue and operation strategy," in The Principles of Environmental Economics: A Guide for Students and Decision Makers, H. Dlm. Folmer, H. L. Gabel, and Hlm. Opschoor, pp. 413-439, United Kingdom: Edward Elga Publishing Ltd., 1995.

[20] S. L. Hart, "A natural resource-based view of the firm," Academy of Management Review, vol. 20, no. 4, pp. 986-1014, 1995.

[21] B. Beamon, "Designing the green supply chain," Logistics Information Management, vol. 12, no. 4, pp. 332-342, 1999.

[22] Q. Zhu, J. Sarkis, and Y. Geng, "Green supply chain management in China: pressure, practices and performance," International Journal of Operation and Production Management, vol. 25, no. 5, pp. 449-468, 2005.

[23] P. Rao and D. Holt, "Do green supply chains lead to competitiveness and economic performance?" International Journal of Operations \& Production Management, vol. 25, no. 9, pp. 898-916, 2005.

[24] M. Laroche, J. Bergeron, and G. B. Forleo, "Targetting consumers who are willing to pay more for environmentally-friendly products," Journal of Marketing, vol. 18, no. 6, pp. 503-520, 2001.

[25] J. F. Affisco, F. Nasri, and Paknejad, "Environmental versus quality standard-an overview and comparison," International Journal of Quality Secience, vol. 12, no. 1, pp. 5-23, 1997.

[26] D. Holt and A. Ghobadian, "An Empirical study of green supply chain management practices amongst UK manufacturers," Journal of Manufacturing Technology Management, vol. 20, no. 7, pp. 933-956, 2009.

[27] X. Jun, "Model of cluster green supply supply chain performance evaluation based on circular economy," in Proc. of the $2^{\text {nd }}$ IEEE 
Intenational Conference on Intelligent Computation Technology and Automation, 2009, hlm.941-944.

[28] Boeing. (2009). [Online]. Available: http://www.boeng.com.

[29] T. K. Eltayeb and S. Zailani, "Going green through green supply chain initiatives towards environmental sustainability," Operat. Supply Chain Manage, vol. 2, pp. 93-110, 2009.

[30] R. Yin, "Case study research," Design and Methods, Edisi ke-3, Beverly Hills, CA: Sage Publishing, 2003.

[31] W. J. Stenvenson, Operations Management, Edisi ke-9, New York: Mcgraw Hill Irwin, 2007.

[32] L. J. Krajewski and L. P. Ritzman, Operation Management Strategy and Analysis, USA: Addison Wesley Publishing, 1999.

[33] J. B. Ayers, Supply Chain Project Management: A Structural Colalboration and Measurable Approach, USA; St. Lucie Press, 2004.

[34] J. Sarkis, "Manufacturing Strategy and environmental consciousness," Technovation, vol. 15, no. 2, pp. 79-97, 1995

[35] J. Anthony, K. Leung, G. Knowles, and S. Gosh, "Critical success factors of TQM implementation in Hong Kong industries," International Journal of Quality \& Reliability Management, vol. 19, no. 5 , pp. 551-566, 2002
[36] S.-F.Chiang, C.-C.Wei, T.-H. Chiang, and W.-L. Chen, "How can electronics industries become manufacturers in Taiwan and Japan," Clean Technology Environment Policy, Springer-Verlag, 2010.

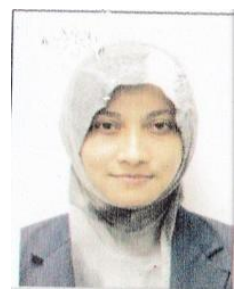

Norlinda Binti Mohd Rozar graduated with economics degree from North University Malaysia, 2002. She then completed Master of Technology Management in University Malaysia Pahang, 2011. She is currently completing a PhD of Technology Management in University Malaysia Pahang, 2012/2013. Norlinda has worked at various practices in Malaysia, industry since 2003. Her work area of finance and company management. She has start work as a Finance Executive, prepare financial statement and monthly forecast of the company. At the same time she organize and conducted internal training for staff's.

In 2008, she has also worked in audit area for SOX (Sarbanes Oxley) in a one of the Brussels company in Malaysia. Currently, she has own business in training consultation for some institute of education. Therefore, she is to go further in research in term of technology management. 